\title{
Dolga zgodovina industrije v Ajdovščini Osredotočeni obrati ob Hublju (oris od i6. do začetka 20. stoletja)
}

\author{
Ines Beguš \\ Goriški muzej Kromberk - Nova Gorica \\ ines.begus@goriskimuzej.si \\ UP FHŠ, Oddelek za zgodovino in Inštitut za medkulturne študije \\ ines.begus@fhs.upr.si
}

\section{Uvod}

Današnje mesto Ajdovščina je primer industrijskega kraja, ki se je razvil na podeželju. Razvoju industrijskih dejavnosti lahko sledimo vsaj od 16. stoletja dalje, ko so $\mathrm{z}$ delovanjem pričele fužine, vse do 21. stoletja. Ta kontinuiteta in umeščenost $\mathrm{v}$ podeželje predstavljata osrednjo temo pričujočega prispevka. Eden ključnih dejavnikov gospodarskega razvoja kraja je bila nedvomno reka Hubelj, ki je nudila dobre pogoje številnim mlinom, žagam, fužinam in prvim modernim industrijskim obratom, ki so izkoriščali njen vodni vir in vodno silo. Poleg tega je Hubelj v preteklosti imel še eno vlogo. Že v srednjem veku je postal mejna reka med vipavskim in goriškim gospostvom ter dominijem, po priključitvi goriške grofije habsburškim dednim deželam v začetku 16. stoletja pa mejna reka med deželama Kranjsko in Goriško (Pavlin 2017, 133-34). Obenem je reka v 19. stoletju delila katastrski občini Ajdovščina in Lokavec, ki sta spadali na goriško stran in katastrsko občino Šturje, ki je bila na kranjski strani.

$\mathrm{O} »$ obhubeljski industriji « je bilo razmeroma veliko napisanega. Začetke tovrstnih del lahko pripišemo domačinom in krajevnim zgodovinarjem in delujočim v Ajdovščini (npr. Jurca v Edinost, 7. 1. 1927; Plesničar 1997; Čibej 2005), ki so se ukvarjali s polpreteklo zgodovino kraja ali pa so kot sodobniki sočasna dogajanja, spomine in pričevanja beležili v svojih zapisih. $S$ tem so postavili temelje nadaljnjim piscem, ki so se oprli nanje in se pretežno usmerili v raziskovanje posameznih dejavnosti ali obratov (S. Bačar, D. 
Krečič, J. Krečič). Bistveno manj številni so znanstveni prispevki. Z izjemo papirnice in ajdovske predilnice, ki ju zasledimo tako $\mathrm{v}$ italijanski kot slovenski sodobnejši literaturi, se poglobljenemu raziskovanju zgodovine ajdovske industrijske dediščine zgodovinarska stroka še ni temeljiteje posvetila. ${ }^{1}$

Predstavljene vsebine so nastale na podlagi raziskave o industrijski dediščini Ajdovščine za istoimenski razstavni projekt, ki ga pripravlja Goriški muzej. Osvetlitev doslej manj vidnega primera neagrarne ekonomije na primorskem podeželju obenem predstavlja prispevek k projektu na UP FHŠ. V prispevku obravnavamo le osredotočene obrate, ki predstavljajo industrijsko zgodovino in dediščino Ajdovščine od začetka novega veka do konca 19. stoletja. Obrati, ki so že bili deležni bolj poglobljene obravnave, so tu predstavljeni pretežno na podlagi strokovne literature, medtem ko je večji poudarek namenjen tistim, ki so bili doslej manj raziskani. Pri slednjih je mogoče podati nekatere nove informacije in dognanja, s katerimi dopolnjujemo doslej znano. ${ }^{2} S$ kombiniranjem obstoječe literature in neobjavljenih virov ter $z$ dolgoročnim, večstoletnim, pogledom se nam izriše prva celovitejša slika industrijske zgodovine Ajdovščine, čeprav s tem niso izčrpani raziskovalni potenciali tako kraja samega kot razpoložljivih virov. $\mathrm{V}$ prispevku so posamezni obrati razvrščeni glede na njihovo lego ob reki Hubelj in na njihovo kronološko sosledje. V zaključnem delu podajamo nekateri prve izsledke in interpretacije.

\section{Fužine ob Hublju: od železa do bakra}

Najvišje, ob zgornjem toku Hublja, nedaleč od njegovega izvira, so od 16. do začetka 20. stoletja obratovale fužine. Prvo zamisel o vzpostavitvi železarskih obratov ob Hublju je izrazil plemič Jurij Edling leta 1551 v pismu graški komori, v katerem je zaprosil za dovoljenje za postavitev plavža, talilnice in kovačije na obeh straneh Hublja, vendar je bila njegova prošnja zavrnjena (Bačar 2007, 99-100). ${ }^{3}$ Podobno idejo je leta 1559 ponovno izrazilo pet družabnikov v obliki prošnje, ki so jo najprej poslali vipavskemu gospodu grofu Lanthierju. Pavel Pregel, Andrej Pregelj, Felicijan Gompa, Pavel Junaver

Kot redki izjemi je mogoče navesti omembe Ajdovščine in Šturij v Granda 1984 in Golec 2007. Krečič in dr. Robert Devetak, za kar se jima na tem mestu najlepše zahvaljujem. ner leta 1909, prevod dela njegove knjige ter nekaterih arhivskih virov pa je objavil Stanislav Bačar. Müllnerjevo delo je bilo poznano tudi Edmundu Čibeju (2005, 188 203). 
in Hans Godina so v njej navedli, da so na Colu na gori Napredalo, ki se razteza proti dolini Vodic, pred letom dni našli železovo rudo, zato so želeli ustanoviti fužino ob reki Hubelj, kjer bi izdelovali železarske izdelke, kot so žeblji, podkve in podobno. Grofa so zaprosili za najem zemljišča od izvira Hublja do vključno kmetije, ki se imenuje Saberda, kot tudi doline Vodic, kjer bi lahko izkoriščali les, pražili rudo ter celo zgradi plavž (Bačar 2007, 100).

Grof se je ob njihovi prošnji obotavljal, zato so enako pismo naslovili neposredno na cesarja. Ta je kranjski deželni oblasti naložil, naj imenuje komisijo, ki si bo ogledala kraja, kjer bi obratovala rudnik in fužine. Komisija je ugotovila, da so bili izpolnjeni vsi pogoji, potrebni za zagon fužine - to so nahajališče rude na gori Napredalo, prisotnost vodnih virov tako $\mathrm{v}$ dolini Vodice (kjer je kasneje tudi deloval plavž) kot same reke Hubelj ter obilni lesni viri v prostranem gozdu, ki bo omogočal pridobivanje oglja za fužino (Bavčar 2007, 102). Na podlagi pozitivnega mnenja komisije je cesar Ferdinand 12. novembra 1561 izdal koncesijo, v kateri "potrjuje dva plavža ob potoku Hubelj ter $\mathrm{v}$ dolini Vodic in dovoljuje trgovanje z železom ter poljubno prevažanje železa« (Bačar 2007, 104). Določeni so bili tudi nekateri pogoji. Hubeljsko železo so morali označevati s posebno oznako, da ga je bilo mogoče ločiti od ostalega. Konkurenčnost so omejevali tako, da so za železo oziroma za njegov prevoz in prodajo morali komori plačevati enako višino prispevkov, cestnin in mitnin, carin ter drugih pristojbin kot koroške in zgornjekranjske fužine. V primeru, da bi hubeljske fužine gospodarsko škodovale ostalim, bi morale nemudoma prenehati z obratovanjem brez povračila stroškov. Tako so fužine ob Hublju po skoraj desetih letih načrtovanja pričele delovati. Sprva so $\mathrm{v}$ fužinah pridobivali volk oziroma surovo železo, ki so ga nato predelali v kovno železo in jeklo. Kasneje so pričeli s pridobivanjem grodlja. V prvih letih so predelali okrog 12 ton železa, šest let kasneje, po zamenjavi peči, pa so lahko presegli 100 ton letno. Kot kraji izvoza se omenjajo Benetke, Tržič, Gorica, Gradiška in Trst (Bačar 2013a, 267-68).

Že od same postavitve so se družbeniki fužin ob Hublju soočali z zahtevnimi razmerami in visokimi stroški obratovanja. O tem pričajo različni viri iz obdobja med letoma 1567 in 1572 . Poleg mitnin, cestnin in drugih dodatkov so fužinarji morali skrbeti za stavbe in celo za prometno infrastrukturo. Do obratov ni bilo urejenih poti, zato so morali sami poskrbeti za izgradnjo novih cest, saj so ležali na težko dostopnem območju, kar je povzročalo visoke stroške prevoza oglja. Glede delovne sile za prevažanje rude, premoga in železa niso mogli računati na okoliško kmečko prebival- 
stvo, saj »se ljudstvo tukaj ob težkem obdelovanju vinogradov« tej dejavnosti ni moglo posvečati. Drugače je bilo z delom v proizvodnji, saj so bili v obratih zaposleni kmetje, ki pa se niso spoznali na rudarski red in varen načina dela. Leta 1567 je upravnik fužin poročal o orkanski burji, ki jim je nekajkrat popolnoma uničila in porušila fužine, kar je posledično prinašalo zastoje dela in dodatne stroške za ponovno postavitev stavb (Bačar 2007, 167-68, 170; Bačar 2013a, 268). A povsem očitno težave niso bile tolikšne, da bi zavrle obrate, saj so svojo dejavnost širili. Že leta 1576 so družabniki zaprosili za 25-letno koncesijo za postavitev livarne, v kateri bi lahko surovo železo predelovali v litino, kar jim je tudi uspelo.

Kmalu zatem sta fužine prevzela podjetnika brata Hieronim in Hanibal Gnecco. Kdaj in kako natanko je do tega prišlo, ni znano, a viri razkrivajo, da je Hieronim najkasneje leta 1587 nadaljeval delo v fužinah ob Hublju. Da je šlo za dokaj ambicioznega podjetnika, priča dejstvo, da je z zaslužkom od obdelave grodlja ob Hublju in v drugih obratih, ki jih je posedoval v Brekovicah na Gorenjskem, nameraval poravnati del kupnine za fužine ob Kanomlji pri Idriji. Zaradi težav pri pridobivanju soglasij k izvozu v Italijo in posledični zadolženosti mu je bil grodelj odvzet, dokler ne bi povrnil dolgov. To je zanj pomenilo velik izpad dohodka, kar je privedlo do propadanja njegovih fužin. Zaradi ustavitve dela in močnih vetrov so bile do leta 1595 hubeljske fužine opuščene (Bačar 2007, 106, 111-14; 2013a, 26869; Blaznik 1938, 39).

Mirovanje fužinarske dejavnosti ob Hublju je trajalo vse do leta 1659, ko je cesar Leopold ugodil prošnji grofa Antona Lanthierja ter mu izdal dovoljenje za ponovno vzpostavitev zapuščenega rudnika železa ter fužin (Bačar 2013a, 269). Kranjski polihistor Janez W. Valvasor omenja, da je "posestnik gospostva Vipava dal postaviti fužino in topilnico železa ter tu liti in kovati različne železne predmete, na primer železne retorte za Idrijo za pridobivanje živega srebra iz rude in še več podobnih izdelkov«. Po Valvasorjevem pričevanju naj bi omenjena fužina zgorela v požaru (Valvasor 2009, 2795).

O fužinah v obdobju 17. stoletja sicer obstaja še ena razlaga, ki pa zaenkrat nima podlage $\mathrm{v}$ arhivskih virih. Po družinskem izročilu, ki ga je zapisal Jurca (Edinost 7. 1. 1927) in je skozi čas dobilo nekaj različic, naj bi območje fužin že od prve polovice omenjenega stoletja posedoval Krištof Schlegel. Ta naj bi se v naše kraje priselil iz Šlezije ter od grofa Lanthierja odkupil širše območje ob Hublju. Jurca domneva, da so bile Lanthierjeve fužine, ki jih omenja Valvasor, pravzaprav »Schleglove Fužine ob Hublju«, 
ki naj bi se v obdobju slabega stoletja razvile že v pravo vas ter cvetočo »veleindustrijo železnih in bakrenih izdelkov«.

Železarska dejavnost se je nadaljevala tudi v 18. stoletju, pri čemer je dejansko prišlo do nekaterih sprememb. V drugi polovici stoletja se na območju Šturij še omenjajo "fužine", in sicer dve za železo in ena za baker ter nekaj delavskih bivališč (Rajšp in Trpin 1997, 102). Pisni viri pa zanesljivo pričajo o tem, da je v začetku 19. stoletja delovala "proizvodnja« bakrenih izdelkov družine Schlegel. Baker so trgovci in kovači pošiljali preko furmanov. Iz njega so izdelovali raznovrstne bakrene izdelke, izdelane po naročilih kupcev. Med njimi se najpogosteje naštevajo raznovrstni kotli za različne namene, kot so kuhanje žganja in varjenje piva, pranje in barvanje, poleg tega še orodje, posode za ogrevanje postelje ter različne vrste posod, ponev, skled in vrčev za vodo. Izdelovali so tudi bakreno žico ter bakrene plošče, s katerimi so oblagali trupe ladij. Njihove izdelke so med drugim italijanski trgovci izvažali v kraje, kot so Neapelj, Sicilija in Lombardija (AS 731).

Fužinarsko dejavnost v prvih desetletjih 19. stoletja potrjuje tudi franciscejski kataster, ki v Šturjah navaja dve topilnici bakra $\mathrm{z}$ desetimi kurišči. Zaposlovali sta devetnajst delavcev, njuna letna proizvodnja pa je znašala enajst dunajskih centov bele bakrene pločevine. Surov baker - zgoraj navedeni arhivski viri omenjajo, da so predelovali tudi star baker - naj bi dobivali iz Trsta in Dunaja. Tu sta delovali še valjarna bakra z dvema kuriščema in valjem, kjer so delali še štirje delavci, ter kovačija, v kateri so iz železa, ki so ga dobivali iz Štajerske, izdelovali železne posode in orodje. Imela naj bi eno kladivo in dve ognjišči ter običajno zaposlenih pet delavcev, ki so letno predelali 200 centov železa (Granda 1984, 64-65).

Dejavnost družine Schlegel je s časom doživela zaton. V fužinah se je nato izmenjalo nekaj lastnikov, obrati pa so z delovanjem dokončno zaključili tik pred prvo svetovno vojno. Njihov zadnji lastnik je bila Ema Guyer, ki je obrate delno podedovala po očetu in tovarnarju v bližnjih Palah Henriku Rieterju. Nižje pod fužinami je Ema Guyer na skici v svojem zapisu, v katerem zagovarja vodne pravice do reke Hubelj, izrisala še eno kovačijo ( $b a-$ ttirame), ki je stala v bližini njene hiše (ASGO, GC, 676, 2303) in ki jo omenja tudi Čibej $(2005,206)$.

\section{Nussbaumovi raznovrstni obrati na Fužinah}

Naslednji obrati, ki so delovali ob Hublju v 19. stoletju, so bili obrati Jožefa Adalberta Nussbauma in kasneje njegovega sina Avgusta. Jožef je bil po rodu iz Dunajskega Novega mesta. Poročen je bil s Katarino Schlegel, hčer- 
ko Filipa, lastnika fužin (ŠAK, ŽV, SA II). Na platoju tik nad območjem Pal je leta 1837 zgradil žago za razrez furnirja. Pri vodenju gradnje in delavcev mu je pomagal tast Filip (npr. AS 731, dok. 20. 8. 1845). Poleg žage je najverjetneje $\mathrm{v}$ njegovem času obratoval tudi mlin za čreslo, $\mathrm{s}$ katerim je mlel naravne materiale (ruj) za izdelovanje barvil (Plesničar 1997, 90). Lesna dejavnost sicer ni bila njegova edina dejavnost, saj se $\mathrm{v}$ arhivskih dokumentih pogosto pojavlja tudi kot izumitelj in prijavitelj patentov za svoje zamisli. Sodeloval je z lastniki družb in posamezniki, ki so potrebovali stroje ali pripomočke, s katerimi bi izboljšali svojo dejavnost. Med njimi se npr. omenja Industrijska družba v Palah, o kateri bo več zapisanega kasneje. Leta 1873 je s sinom na dunajski razstavi predstavil turbine, ki sta jih zasnovala, in izdelke iz furnirja iz svoje mehanične žage (OGC-WA 1873, 508, 532).

Jožefu je pri delu sledil sin Avgust. Ta je leta 1892 ob Hublju postavil tovarno testenin in se tako preskusil v novi panogi. Kje točno je bila njena lokacija, ni popolnoma pojasnjeno, najverjetneje je stala ob domačiji in žagi, v neposredni bližini struge Hublja. Njeni izdelki so bili glede na Nussbaumovo reklamo v obliki pesmice $\mathrm{v}$ časopisju precej raznovrstni, prav tako se tovarnar v njej hvali tudi s stroji, ki so »mesili testo in izdelovali testenine«(SN, 2. 7. 1892). Obratovanje tovarne je že po dveh letih prekinil hud požar, ki je poleg poslopja uničil še vse izdelke, pripravljene za prodajo. Škoda je bila ogromna, saj je bila notranjost tovarne večinoma iz lesa, Avgust Nussbaum pa je poleg tovarne izgubil tudi ves dobiček od neprodanega blaga (Slovenec, 12. 5. 1894).

Avgust je nato tri leta po požaru na istem mestu, kjer je stala tovarna testenin, postavil galvanoplastični obrat za izdelovanje bakrenih kotlov, in sicer "prvi te stroke v naših slovenskih krajih«. Kotle je izdeloval s postopkom galvanizacije. Na kalup poljubne oblike je $\mathrm{z}$ galvanizacijo "nanašal« baker in tako dobil kotel. Ti so bili še posebej kvalitetno izdelani na dnu in ob »kolenu dna«, kjer so običajni kotli najhitreje počili, česar »v galvanoplastiki pred njim niso umeli«. Kotel je nato ločil od kalupa tako, da je med njiju usmeril vodo pod pritiskom. Svoje zamisli, do katerih je prišel ob izdelavi kotlov s pomočjo galvanizacije, je Avgust tudi patentiral (Soča, 16. 4. 1897). Za potrebe izdelave kotlov je zgradil manjšo elektrarno s Francisovo turbino moči $30 \mathrm{KM}$ in dinamom moči $20 \mathrm{~kW}, 110 \mathrm{~V}$ (Zupanc in Falatov $1976,34)$. Nussbaum je bil torej vsestranski človek, nadaljeval je tudi s snovanjem turbin. Tako je leta 1905 »iznašel« turbino za tovarno testenin v Ilirski Bistrici (Slovenski narod, 17. 5. 1905). 
Leta 1920, deset let po Avgustovi smrti, je njegove nepremičnine in obrate kupil Miroslav Bratina (ASGO, GC, 705, 2701), brat izumitelja Franja Bratine, znanega predvsem na področju letalstva. Miroslav je že leto kasneje stavbo tik ob Hublju ter del drugih nepremičnin znova prodal, in sicer novoustanovljeni družbi »Elektrarna na Hublju, družba z omejeno zavezo«, $\mathrm{v}$ kateri sta $\mathrm{z}$ bratom in drugimi ajdovskimi pomembneži delovala kot družabnika (PANG, TG, 296, C. 1-23).

\section{Pale: $v$ začetku so bili mlin, pivovarna, žganjarna, obrat za luščenje žita}

Na desni strani struge Hublja, na območju današnjih Pal, je leta 1808 mlinar Anton Svetina ob reki Hubelj sklenil trajni zakup (perpetuo emphiteusi) za »zemljišče, ki se mu reče Paloch « z Marto Edling, ženo grofa Karla Edlinga, ki je po moževi smrti posedovala omenjeno zemljišče. Obenem mu je dovolila, da na njem postavi »mlin s štirimi mlinskimi kamni in eno žago s tolkačem ter naredi grablje" (un molino a quatro mole, ed una sega, con pestello col farvi una Rosta, ASPG, ASP II, 578). Kot kaže franciscejski kataster, je Svetina do leta 1822 tam ob reki imel kompleks treh večjih in dveh manjših stavb, opredeljenih kot "stanovanjska hiša, mlin in hlevi«, čigar stavbna parcela je $\mathrm{z}$ dvoriščem skupaj merila $1.500 \mathrm{~m}$, do katerih je bil iz Hublja speljan vodni kanal (AST, CF, M, 254b IX in SE, 399/4 PBP).

Sredi 19. stoletja so na mestu Svetinovih obratov pričeli $z$ delovanjem novi obrati. O njih obstaja več zapisov, $v$ katerih se podatki o začetkih delovanja, lastništvu, tehniki, uspešnosti in njihovemu zatonu precej razlikujejo. Dodatni viri, ki smo jih do sedaj uspeli pridobiti, še ne omogočajo oblikovanja dosledne slike o navedenem. Zato bomo sledili zaporedju tistih podatkov in virov, na katere se lahko zanesljivo opremo, in poskusili na nekatera zastavljena vprašanja podati odgovore, ki pa bodo zaenkrat zgolj hipotetični.

Iz popisa gospodarskih subjektov izvemo, da je bila leta $1852 \mathrm{v}$ Trstu ustanovljena »Industijska družba v Palah«, ki je leta 1856 že posedovala mehanični mlin in pivovarno v Ajdovščini (HSHKÖ 1856, 426). O tem, da »ravno letos neki Tržačanje nad Ajdovskim tergom na potoku Hublj velike poslopja za fabrike zidajo«, je nato poročalo časopisje novembra leta 1853 (Novice, 5. 11. 1853, 356). Eno leto kasnejšo letnico nosi načrt pivovarne, iz katerega je razvidno, da gre za veliko in mogočno zgradbo, ki je, ko je bila zgrajena, stala v Palah na levem bregu Hublja. V vzhodnem delu stavbe so bili načrtovani prostori za shranjevanje ter prostori za sušenje kaljenega 
ječmena. V spodnjem, deloma tudi podzemnem delu stavbe naj bi bile kleti, $v$ prizidku poleg pa prostori za maceracijo. $V$ prostorih $\mathrm{v}$ osrednjem delu zgradbe naj bi potekal proces varjenja piva, $\mathrm{v}$ skrajni zahodni polovici pa so bili načrtovani prostori za njegovo hlajenje ter dodatne kleti. Omenjeni načrt navaja, da gradnjo pivovarne snuje »Industrijska družba na območju obratov v Palah« v kraju »Saberda« v občini Šturje, na njem pa sta podpisana Nikola Lazovič kot nadzornik v družbi ter že omenjeni mehanik in izumitelj Jožef Nussbaum (načrt hrani V. Bizjak). Lazovič in Nussbaum sta sodelovala tudi leta 1856, o čemer nam priča osnutek pogodbe za izgradnjo obrata oziroma »izdelavo aparata za kuhanje žganja, ki bo stal v stavbi na levem bregu Hublja blizu mostu ", ki naj bi ga v celoti zasnoval in tudi izvedel gradnjo Jožef Nussbaum (ARS 731, 4. 2. 1856). Istega leta je Lazovič prejel desetletni privilegij za stroj za luščenje ječmena in riža (ALZ, 15. 12. $1856,969)$. Leto kasneje je pravico do rabe omenjenega privilegija prenesel na Industrijsko družbo, družba pa je smela to pravico koristiti do konca izteka privilegija in izključno na lokaciji svojih obratov pri Ajdovščini (ALZ, 25. 2. 1858, 117).

Nov časopisni vir, ki nam je trenutno znan, je iz leta 1865 . V njem se omenja prodaja obratov pri Ajdovščini, in sicer mehaničnega mlina s turbino, obrata za luščenje ječmena in riža, žganjarne in pivovarne (Tagespost, 6. 7. 1865). Točen čas začetka obratovanja mlina nam trenutno ni znan, kot že omenjeno, je deloval vsaj že od leta 1856 . Zgrajen je bil na desnem bregu Hublja, kjer so poprej stali Svetinovi obrati. Dejansko je na tem mestu na karti franciscejskega katastra iz leta 1873 dobro viden bistveno razširjen, po površini vsaj podvojen kompleks stavb v primerjavi s Svetinovim časom (AST, CF, M, 254C 9). Mlin se v poročilu Gospodarske zbornice za leto 1858 ne omenja posebej (CCIG 1858), se pa omenja v poročilu zbornice iz leta 1889. V njem je zapisano, da je $\mathrm{v}$ začetku tistega leta mlin prenehal $\mathrm{z}$ delovanjem. Sicer je še leta $1888 \mathrm{v}$ »mehaničnem mlinu« delalo 43 delavcev (operai), njegova proizvodnja istega leta pa je bila približno 30.000 kvintalov moke, »kar predstavlja vrednost približno 300.000 goldinarjev, v primerjavi s proizvodnjo okoli 9oo.ooo goldinarjev, ki jo je dal 15 let nazaj«, kot je zapisala gospodarska zbornica (CCIG 1888, 26-27). V poročilu je še zavedeno, da je prenehanje delovanja mlina gospodarsko precej prizadelo prebivalstvo večjega dela doline.

Zadnji upravljavec še delujočega mlina je bil tržaški trgovec Henrik Rieter. Ta se v zvezi z mlinom in mlinskimi izdelki omenja vsaj od leta 1873 (LZ, 17. 7. 1873, 1146). Leta 1884 je formalno dejavnost še razširil. Svojo druž- 
bo z nazivom »Industrijski obrati v Pally pri Ajdovščini, Mlin H. Rieterja« (Stabilimenti industriali di Pally presso Aidussina, Molino di H. Rieter) s sedežem v Palah je vpisal v trgovski register, saj se je »že več let « ukvarjal tudi $s$ trgovino z žitom in moko. Leta 1899 je zastopnik Rieterjeve hčerke in dedinje Eme Guyer družbo izpisal iz registra, saj naj bi ta prenehala obstajati že deset let prej, torej istega leta, kot je prenehal delovati mlin (PANG, TG, 250, I-41).

Po Bačarjevem opisu, ki je verjetno nastal na podlagi fotografij, zapisov in terenskega dela, naj bi bil mlin štirinadstropna stavba v obliki črke U. Na južnem, torej sprednjem, delu je stavba segala v širino približno 25 metrov, kraka pa sta bila dolga približno 20 in visoka 13 metrov. Skoznjo je tekla pot na levi breg čez kamniti ločni most. Voda, ki je poganjala mlin, je bila speljana po vodnem kanalu z začetkom tik pod Nussbaumovim obratom, kasnejšo elektrarno. Pred mlinom na severni strani je stala tudi Rieterjevega žaga (Bačar 2013b, 42-43).

Leta 1906 je Avgust Nussbaum v časopisnem oglasu prodajal turbino, mlinske kamne, kar 30 strojev za sejanje in razvrščanje izdelkov in druge predmete iz mlina ter stroje, pumpe in posode iz pivovarne »onemu, ki največ obljubi« (Soča, 1. 8. 1906). Tri leta kasneje je najemnik obratov v Palah postalo podjetje Moser-Steckleing und Sprech, ki je mlin in pivovarno preuredilo v tovarno konzerv. Podjetje je delovalo le do leta 1911, še istega leta je prostore za obdobje enega leta najelo podjetje Voltaverke iz Linza, ki je izdelovalo električne aparate. V zgradbah se je nato med prvo svetovno vojno naselila avstro-ogrska vojska (ASGO, GC, 676, 2301).

\section{Mlin za papir: od Lanthierija do Kumarja (1670-1818)}

Prvi danes znan mlin za papir ob Hublju naj bi postavil grof Anton Lanthieri na mestu pogorelih fužin. Poleg tega je omenjeni grof posredoval tudi suknarsko delavnico (Valvasor 2009, 2795; Morelli 1855, 179-80), kar priča o tem, da je bil takratni vipavski gospod precej podjetnega duha. Kot piše Bačar, je za postavitev predilnice in tkalnice volne ob Hublju zaprosil leta 1682. Suknarna naj bi zaposlovala »nekaj sto ljudi«, kar pomeni, da je Lanthieri načrtoval velik obrat. Uspešno je obratovala še leta 1693, ko je prejela naročilo 180 kosov sukna v zeleni, rdeči in modri barvi (AN, 15. 9. 2011, 9).

Lanthierjev mlin za papir naj bi domnevno deloval v letu 1670, pri čemer Šorn nakazuje na možnost, da je ta prvi obrat propadel že po enem letu in da je bil kmalu po letu 1734 na novo postavljen ali obnovljen na mestu, 
kjer je že prej stal podoben obrat (Šorn 1954, 91). O tem, da je s papirnico, "s katero je v preteklem stoletju zaman poskušal Anton grof Lanthieri«, v drugi polovici 18. stoletja »enako pogumno" pričel Tomaž Kumar in jo »s precejšnjim razumevanjem nekaj let vodil v Ajdovščini«, piše tudi Morelli (1855, 137). Tedaj je namreč goriški trgovec in izdelovalec igralnih kart Tomaž Kumar »za isti namen« odkupil ruševine stare Lanthierjeve papirnice in na njenih temeljih zgradil novo (Iancis 2001, 114). Lokacija mlina je sicer negotova, ${ }^{4}$ a kot kaže, je Lanthierjeva papirnica delovala na istem mestu kot kasneje Kumarjeva, ki je postala ena najuglednejših v slovenskih deželah konec 18. stoletja, ${ }^{5}$ to je ob srednjem toku reke Hubelj, v bližini sotočja Hublja in potoka Lokavščka.

Tomažu Kumarju se je priložnost za posel ponudila, ko jo takratna državna oblast obljubila podporo novim investitorjem, ki bi izdelovali papir na območju dežele Goriško-Gradiške. Tako je investiral v izgradnjo papirnice ob Hublju, ki je pričela delovati maja 1767 (Iancis 2001, 113-14). Iancis je na osnovi arhivskih virov uspel precej natančno rekonstruirati stavbno zasnovo papirnice, naprave za izdelovanje papirja ter proces dela. Dvokrilni kompleks papirnice je obsegal 405 korakov. Imel je 8 vrat s kamnitimi oboki ter 54 velikih in malih oken. Na vzhodnem delu sta se pomikali dve nadlivni vodni kolesi. Na zahodni strani je vzporedno z obratom, vendar ločeno od njega, stala stavba, namenjena bivanju zaposlenih. Ogrevali so jo 4 kamini in 3 peči, $v$ njej pa je med drugim stal tudi oltar iz afriškega marmorja. K papirnici so spadali še hlevi in manjše hiške ter dolg ograjen vrt. Kompleks je zaokrožala zgradba, namenjena vzporedni proizvodnji svile, kjer so se nahajali kotli, v katere so polagali kokone in jih segrevali s pečicami (forneli). Prostore papirnice so zapolnjevale naprave za izdelavo papirja. Vodna kolesa so poganjala 48 stop, ki so v kadunjah pod njimi surovino spreminjale $\mathrm{v}$ drobno zmleto kašo. Leta 1771 je papirnica postala bogatejša za »holandca", mlina za mletje osnovne mase, ki je pospešil proces dela. Na oddelku s kadmi so se nahajali še kalupi, čebri, zabojniki, valji za glajenje papirja, preše ter dva vzidana bakrena kotla za lepilo (klej). Sušenje papirja se je odvijalo na lesenih letvah pod dvema ponjavama (Iancis 2001, $116,122-24)$.

Müllner v svojem delu domneva, da naj bi fužine delovale vsaj še leta 1690 oz. 1703 (Bačar 2007, 106). Če zaupamo Valvasorjevi trditvi in Müllnerjevi domnevi, potem lahko sklepamo dvoje: da se je del fužinarskega obrata po požaru le ohranil ali pa da ga je Lanthieri postavil na novo. mlin, vendar bi lahko naši trditvi hipotetično pritrdili. 
Papirnica je zaposlovala 24 ljudi, od tega enega mojstra, osem delavcev, dva hlapca in trinajst dnevnih delavcev. $V$ procesu izdelave papirja je sodelovala skupina 4 do 5 ljudi, od katerih so dva ali trije delavci ob kadi izdelovali papir, četrti, pogovorno imenovan trevellin, je pobiral papir, stisnjen med klobučevino, ki je vpijala vodo iz novonastalega papirja, peti, cazzador, pa je skrbel za maso, da je tistim, ki so delali ob kadeh, ni zmanjkalo. Glede na število zaposlenih in delovni proces, ki predvideva delitev dela, to papirnico Šorn $(1954,98)$ uvršča med manufakturne obrate. Normativ, ki ga je Kumar postavil za delovno skupino, je predvideval izdelavo 12 rizmov oziroma $168 \mathrm{~kg}$ papirja na dan. Delovni čas je potekal od 2.30 zjutraj do 19.00 zvečer, $v$ vseh letnih časih, $\mathrm{z}$ enournim odmorom za kosilo in počitek. Šorn domneva, da so nekatera dela, kot so čiščenje, sortiranje in rezanje cunj, v papirništvu opravljale tudi ženske (Iancis 2001, 116, 120; Šorn 1954, 98).

Mojstri so prihajali iz italijanskih krajev in zaradi svojih sposobnosti ter tehničnega znanja imeli pomembno vlogo $\mathrm{v}$ proizvodnem procesu. Vidno vlogo so imeli tudi zbiralci starih cunj iz Gorice, Krmina, Trsta in Reke, ki so Kumarja zalagali s takrat najdragocenejšo in izredno iskano osnovno surovino za papir. Kumar je pri oblasteh uspel doseči prepoved izvoza cunj in izrezkov kož izven meja grofije in si s tem zagotovil monopol za odkup cunj (Iancis 2001, 118, 121).

Kako uspešna je bila Kumarjeva papirnica, pove podatek, da je po dveh letih obratovanja mlina proizvedla med 84 in 98 tonami papirja. Do leta 1775 je imela v svoji ponudbi že 39 vrst papirja štirih različnih kakovosti. Med njimi velja še posebej omeniti (»holandski«) vijoličasti ovojni papir za zavijanje sladkorja, za katerega je Kumar sam izdelal recepturo in si tako pridobil pomembnega kupca, čistilnico sladkorja na Reki. Poleg tega je prejel tudi številne pohvale za kvalitetno izdelavo papirja. Na višku obratovanja je to nedvomno bil največji obrat $\mathrm{v}$ papirniški panogi na današnjem slovenskem ozemlju, kvaliteta papirja pa je bila bistveno boljša kot pri drugih proizvajalcih (Šorn 1954, 93, 95). Težnja h kakovosti je gotovo izvirala tudi iz hude konkurence, ki so jo predstavljali beneški mlini na drugi strani meje. Poleg Reke je Kumar oskrboval še trge na Goriškem, Kranjskem in v Trstu ter si tako zagotovil prodajo papirja tudi tam, kjer so do tedaj uporabljali izključno beneški papir (Šorn 1954, 95, 100; 1984, 131-32).

Leta 1788 se je začel zaton papirnice ob Hublju. Temu so botrovali starost lastnika, vse težje prilagajanje potrebam trga ter konkurenčni obrati. Močno zadolženi Kumar se je leta 1793 odločil svoj mlin prodati Karlu 
Boromeju Fajencu iz Kočevja za ceno 22.0oo goldinarjev. Fajenc, ki je pred tem služboval v čistilnici sladkorja na Reki, je izboljšal proizvodnjo papirja ter za kupca ponovno pridobil čistilnico sladkorja, ki se je po Kumarjevem zatonu obrnila na Benetke (Šorn 1954, 96). Papirnica je leta 1818 prešla v roke Alojza Kutiara. Dejansko ga v franciscejskem katastru leta 1822 najdemo navedenega kot lastnika ogromnega dvokrilnega stavbnega kompleksa, vidnega na katastrski karti v obliki črke »U«, opredeljenega kot »enonadstropno stanovanje, papirni mlin in dvorišče» in čigar stavbna parcela je merila blizu $3.300 \mathrm{~m}$. Cenilni operat katastra to »tovarno papirja« še leta 1830 navaja kot delujočo in kot enega večjih zaposlovalcev v kraju. Kutiaro je v Ajdovščini izdeloval tudi umetne kresilne gobe. Postopek njihovega izdelovanja je bil zelo podoben postopku izdelovanja papirja (AST, CF, SE, 9/4, BP in 10/1, Oec S/5; AST, CF, M 5b I; ASGO, TT, LST, 11O, 143, 685; Slokar 1962, 32).

\section{Jochmannov mlin: od moke do elektrike}

Mlinar Venzel, po rodu iz današnjega Javornika na Češkem, se je pred prihodom v Vipavsko dolino poročil v Podgori pri Gorici z domačinko Marijo Terpin in se nato leta $1867 \mathrm{z}$ družino preselil v Šturje. Še istega leta je ustanovil podjetje Walzmühle Wenzel Jochmann Haidenschaft. Njegov mlin je deloval na mestu, kjer je že poprej stal mlin, katerega zadnji znani lastnik je bil Jožef Majer. Mlin sta sprva tvorili dve zgradbi, ločeni z vmesnim vodnim kanalom, po katerem je teklo devet vodnih koles. Venzel je z izdelki iz tega mlina nastopil tudi na svetovni razstavi na Dunaju in dosegel nekaj medalj (Krečič v Kozmik Vodušek 2017, 144, 158).

Leta 1874 se je odločil za njegovo prenovo, po kateri je mlin postal trinadstropna in tehnološko zelo dobro opremljena stavba. Spremenili so tok vode skozi mlin, mlinska kolesa je zamenjala turbina, skoraj vse mlinske kamne pa moderni mlinski valjčki, »kar je ena prvotnih tovrstnih posodobitev v takratnem evropskem prostoru«. Predelovali so koruzo, ječmen, ajdo in pšenico, ki so jo uvažali z Madžarske, končni izdelki pa so h kupcem potovali v smeri proti Kranjski in Reki ter proti Gorici. Med letoma 1895 in 1896 je ponovno moderniziral mlin, vgradil je še valjčne stroje in naprave za mlinsko čiščenje žit (Krečič v Kozmik Vodušek 2017, 146, 150).

Leta 1902 je lastnik mlina postal Venzlov sin Andrej, ki se je takoj po prevzemu ponovno lotil prenove mlina in nakupa novih strojev (Krečič v Kozmik Vodušek 2017, 137-38). V začetku leta 1905 je z oglasom iskal »spretnega in vestnega delavca«, veščega »računstva«, ki bi hkrati opravljal »delo 
magazinerja in k temu spadajoča ročna dela« (Edinost, 8. 1. 1905). V poletnem obdobju je začasno zaustavil delovanje mlina ter ga prenovil in moderniziral, kar je oznanil tudi v časopisju septembra 1905. V njem je pojasnil, da se sedaj "ne boji nobene konkurence vsled svoje avtomatične oprave in opreme $\mathrm{z}$ najnovejšimi in najboljšimi stroji in siti«, ter napovedal, da bo izdeloval izdelke iz pšenice in koruze ter rženo moko. Kot kaže, pa sta mu nova oprema in zagon novih strojev sprva povzročala nekaj težav. V začetku leta 1906 se je še opravičil kupcem, ker je prihajalo do nekaterih nevšečnosti v novem "avtomatičnem " mlinu zaradi novosti, in zagotovil, da posluje $\mathrm{z}$ osebjem, ki je kos zahtevnim in natančnim nalogam (Soča, 16. 9. 1905; Slovenec, 3. 2. 1906).

$\mathrm{V}$ isti objavi je omenjal tudi to, da je z mlinom »združena« elektrarna. Že naslednje leto je ustanovil »električno podjetje« Ajdovščina-Šturje, ki se je ukvarjalo $\mathrm{z}$ dovajanjem električne energije za domača gospodinjstva. Preko oglasa je oddajal pribl. "40o svetilk«, kako uspešen je bil s to dejavnostjo, pa ni znano (Soča, 14. 4. 1906).

Leta 1909 se je Jochmannov mlin znašel v finančnih težavah (Gorica, 24. 4. 1909). Temu naj bi botrovale splošne gospodarske razmere, med drugim tudi nestabilne cene na žitnem trgu. Mlin je v letih tik pred vojno poslovanje zaključeval z izgubo. Andrej se je leta 1914 poročil s Hilde Zuber in nato kot rezervni nadporočnik padel v prvih spopadih na fronti v Srbiji. O delovanju mlina med vojno ni veliko znanega. Med vojno se je Hilde ponovno poročila $\mathrm{z}$ Rudolfom Hirtom, ki je leta 1918 kot prokurist prevzel vodenje mlina, Hilde pa je leto kasneje postala edini lastnik mlina (Krečič v Kozmik Vodušek 2017, 128, 136-37). Med vojnama je mlin zamenjal kar nekaj lastnikov oziroma družb, ki so upravljale z njim. Po drugi svetovni je bil mlin nacionaliziran ter uradno ustanovljen kot Okrajni mlin Ajdovščina (Krečič v Kozmik Vodušek 2017, 112-13). S tem so bili postavljeni temelji za podjetje, ki še danes uspešno posluje kot proizvajalec testenin, kruha in pekovskih izdelkov.

\section{Predilnica in barvarna}

Ajdovska predilnica je $\mathrm{v}$ slovenskem zgodovinopisju že dobro obdelana, omenjajo jo tudi italijanski raziskovalci Goriške (Luchitta 2001). Zato bomo njeno zgodovino na tem mestu le povzeli po omenjeni in dodatni literaturi ter poudarili njen lokalni in širši pomen.

Začetek njene zgodovine sega $\mathrm{v}$ leto 1826 , ko so tržaški investitorji $\mathrm{z}$ Jožefom Chiozzo na čelu pričeli z gradnjo predilnice na ajdovski strani 
Hublja. Prej kot v dveh letih je bila zgrajena Cesarsko kraljeva mehanična predilnica, »višja in po površini večja od česarkoli do takrat zgrajenega v dolini« (Krečič 2018, 16). Leta 1829 je pridobila še cesarski privilegij, istega leta pa je pričela delovati tudi barvarna bombažne preje (t. i. »farberaj«). Dejavnosti sta se združili leta 1835 in še istega leta prejeli bronasto in zlato medaljo za kakovost barvane preje. Barvarna je leta 1841 veljala kot »največja turško-rdeča barvarna v monarhiji« (Kobe-Arzenšek 1979, 229; Krečič 2018, 18).

V letu 1839 je prišlo do prvih menjav nekaterih lastnikov. Med njimi velja omeniti znanega slovenskega podjetnika Janeza Kalistra, ki se v družbi pojavi leta 1843, ter po njegovi smrti njegova sorodnika Franca Kalistra in Josipa Gorupa, ki sta nato sodelovala pri njenem preoblikovanju v delniško družbo s sedežem v Trstu (nov statut 1871; Kobe-Arzenšek 1979, 21419, 223; Krečič 2018, 18). V zadnjih dveh desetletjih 19. stoletja so v družbo vstopali novi člani, med njimi tudi Leopold Brunner, predstavnik tržaške družbe Jacob Brunner e figli, ki je leta 1881 postal generalni direktor predilnice (Kobe-Arzenšek 1979, 224), v začetku novega stoletja pa še podpredsednik in kasneje predsednik upravnega sveta. Leta 1913 je Armin Brunner pridobil nadzor nad delnicami družbe, ki se je takrat imenovala I. R. priv. Filatoio meccanico di Aidussina. Istega leta je bila predilnica vključena v tekstilni koncern Vereinigte Österreichische Textilindustrie a.g., v katerem je sodelovalo 16 obratov za predelavo bombaža na območju grofij Goriške in Gradiške. Po koncu prve svetovne vojne so nekateri obrati iz koncerna, vključno $\mathrm{z}$ ajdovskim, pripadli Brunnerjem in se leta 1920 preoblikovali $\mathrm{v}$ enotno podjetje Società Anonima del filatoio Meccanico di Aidussina, čigar delnice so bile v stoodstotni lasti podjetja Figli di Jacob Brunner (Ratkajec 2015, 119).

Garancija za rast in uspešnost cesarsko-kraljeve privilegirane predilnice in barvarne $\mathrm{v}$ začetku njenega delovanja je bila nenehna tehnološka modernizacija, ki ji je obrat skrbno sledil. Obrat je sprva deloval na vodni pogon v klasičnem smislu, že deset let kasneje (1839) pa je uvedel tehnično novost, in sicer turbino Fourneyron, ki se je v tistem času uvrščala med najboljše sisteme vodnih koles. Poleg omenjene turbine je imel obrat za pogon tekstilni strojev še turbine Fontaine Jonvale turbine z $20 \mathrm{KM}$ in nizkotlačni parni stroj sistema Watt s 38 KM. ${ }^{6}$ Predilnica je delovala s stroji Thorstle in Mule-Jenny ter opremo znane angleške družbe Platt (Šorn 1984, 237; Krečič 2018, 20; Kobe-Arzenšek 1979, 236). Predelovali so predvsem ameriški, ma-

6 Za razlage posameznih strojev glej Krečič 2018, 20. 
kedonski in egipčanski bombaž, ki je bil najustreznejši za izdelavo fine preje in so ga preko Trsta dovažale ladje avstrijskih ladjarjev in veletrgovcev, tudi lastnikov predilnice. Najprej so v $70 . i h$ letih 19. stoletja predelovali bombaž iz Egipta, Bližnjega vzhoda in Indije, v začetku 20. stoletja pa so bombaž uvažali iz Indije in Brazilije ter ZDA (Kobe-Arzenšek 1979, 250-51).

Znanje in upravljanje predilnice sta slonela na tujih, priseljenih upravnikih, nadmojstrih in mojstrih, medtem ko je bilo za delo na voljo več sto kmečkih otrok, žena in moških iz Ajdovščine in njene okolice. Barvarna in predilnica sta leta 1845 skupno zaposlovali okrog 340 delavcev, ki so proizvedli 343 ton bombažne preje na 12.480 vretenih (Šorn 1984, 237). Število zaposlenih $\mathrm{v}$ ajdovski predilnici se je od njenega odprtja do prvega desetletja 19. stoletja gibalo med 250 in 398 . Med njimi je bil velik odstotek otrok, starih manj kot 14 let. Primerjava števila vseh zaposlenih v petdesetih letih 19. stoletja je pokazala, da je bilo med njimi od 25 do $30 \%$ otrok, mlajših od 14 let. Zaposleni so delali dvoizmensko delo, leto pa je imelo 300 delovnih dni. Kljub nekaterim kršitvam (nočno delo za ženske in otroke, delo otrok ipd.) je družba sicer poskrbela za zaposlene in njihove družine. Izplačevala je nagrade in finančne podpore bolnim ter družinam umrlih delavcev, na voljo so imeli zdravnika in plačana zdravila itd. (Kobe-Arzenšek 1979, 254, 256-57; Krečič v Kozmik Vodušek 2017, 26).

Leta 1881 je predilnico doletel prvi hud požar. Lastniki so se takoj lotili sanacije in tovarna s predilnico, vatarno, barvarno in belilnico je dve leti kasneje že v celoti obratovala. Leto kasneje so se odločili za širitev proizvodnje in $\mathrm{v}$ Romjanu pri Ronkah pričeli z gradnjo tkalnice, ki je do prve svetovne vojne postala že prava tovarna s 1.150 statvami (Kobe-Arzenšek 1979, 239-41). Po drugem uničujočem požaru leta 1894 so se delničarji odločili, da predilnico zgradijo protipožarno. Vse lesene dele poslopij so nadomestili s kamnom in $\mathrm{z}$ betonom, prav tako so lesne strojne dele nadomestili $\mathrm{z}$ železnimi ter dogradili vodni in prašni stolp. Istočasno $\mathrm{z}$ obnovo ajdovske predilnice so se delničarji družbe odločili, da bodo tudi v Ronkah poleg tkalnice zgradili še predilnico (Kobe-Arzenšek 1979, 229-32, 243; Krečič v Kozmik Vodušek 2017, 30).

Leta 1909 so o predilnici znova poročali časopisi, tokrat zaradi dvomesečne stavke tekstilnih delavcev, ki so zahtevali višje plače in odstranitev dveh mojstrov, ki sta z njimi delala surovo. Dvig plač jim je le pogojno uspel, po stavki pa je upravni odbor zamenjal direktorja in enega od mojstrov (Krečič 2018, 34). Istega leta je sicer predilnica odprla nove, moderno opremljene prostore. $\mathrm{S}$ tem je prišlo do sprememb faz $\mathrm{v}$ tehnološkem postop- 


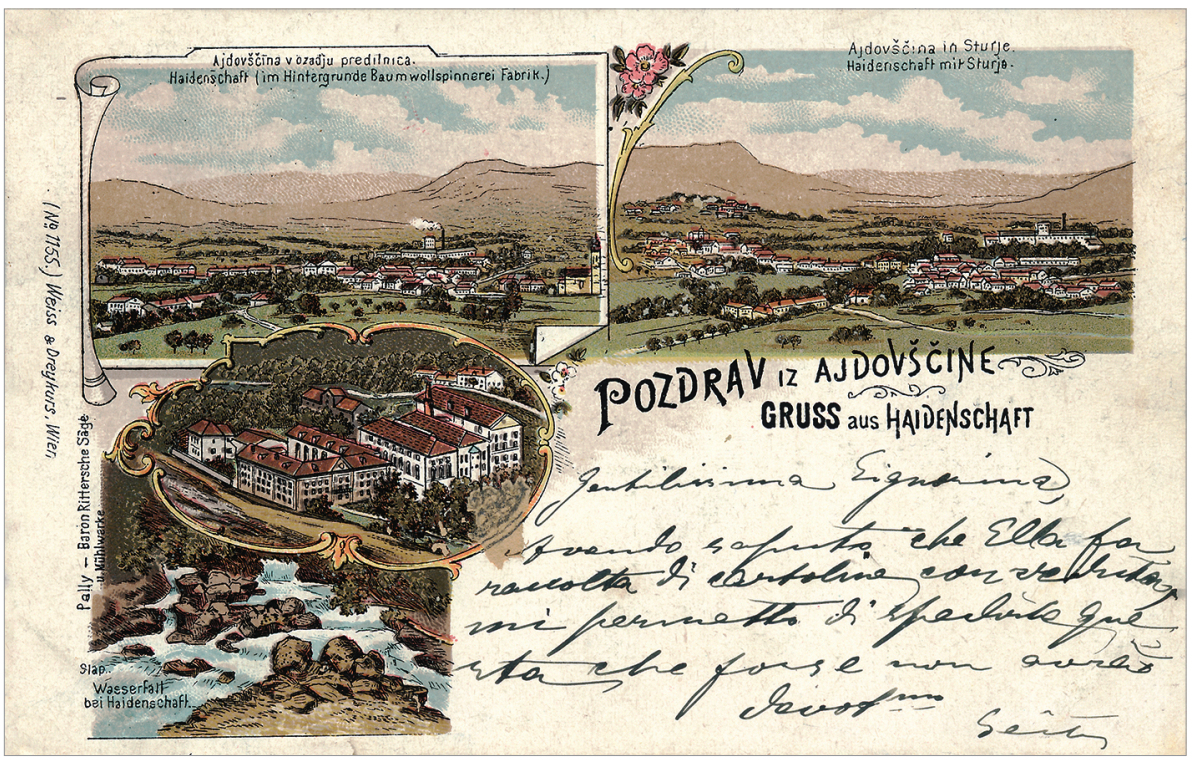

Slika I. Razglednica s konca 19. stoletja: izvir Hublja, veduti Ajdovščine in Šturij, Ajdovščina s predilnico in Pale z mlinom in pivovarno

Vir: Goriški muzej

$\mathrm{ku}$, rezultat pa sta bili izboljšana kvaliteta preje in povečana produktivnost (Kobe-Arzenšek 1979, 233-34).

Vojna je predilniškim objektom prizanesla, v njih si je avstro-ogrska vojska uredila bolnišnico in skladišče. Barvarna je bila preurejena v dezinsekcijsko in dezinfekcijsko postajo. Močno je bila poškodovana ob eksploziji streliva na železniški postaji v Ajdovščini leta 1918 (Arzenšek 1979, 234; Krečič v Kozmik Vodušek 2017, 42). Po vojni je obrat pod vodstvom družine Brunner dobro deloval, dokler takratna gospodarska situacija leta $1927 \mathrm{ni}$ privedla do hude krize podjetja, ki je vodila v stečaj (Ratkajec 2012, 172-76). Po drugi svetovni vojni so leta $1949 \mathrm{v}$ prostorih prejšnje tovarne ustanovili Tekstilno tovarno $v$ Ajdovščini, Ajdovščina (TTA) ter tako ponovno obudili tradicijo tekstilne industrije $\mathrm{v}$ Ajdovščini, ki se še danes uspešno nadaljuje.

\section{Zaključek}

Raznovrstnost panog, ki so se razvile ob reki Hubelj skozi stoletja, kaže na bogato industrijsko tradicijo današnjega mesta Ajdovščina. Začetkom te tradicije lahko sledimo že v predindustrijski dobi oziroma vsaj od sredine 16. stoletja, ko so bile tik pod izvirom Hublja postavljene fužine. Zatem 
je bila prisotnost osredotočenih obratov na območju Šturij in Ajdovščine kontinuirana. Posebej živahna je bila $\mathrm{v}$ dobi začetkov prehoda $\mathrm{v}$ moderno industrializacije $\mathrm{v}$ drugi polovici 18. in na začetku 19. stoletja, ko se ravno ob Hublju razvije manufakturni obrat za proizvodnjo papirja, ter v času industrializacije, ko Ajdovščina in Šturje doživita prvi večji razmah industrijskih dejavnosti, med katerimi posebej izstopata prehrambna in tekstilna panoga. Vse to nam dokazuje, da je bila Ajdovščina ob svojemu agrarnemu značaju obenem industrijsko središče že pred moderno industrializacijo.

\section{Tabela I. Prisotnost industrijskih panog v osredotočenih obratih na območju Ajdovščine skozi stoletja*}

\begin{tabular}{|c|c|c|c|c|c|}
\hline Industrijske panoge & $\begin{array}{l}16 . \\
\text { stoletje }\end{array}$ & $\begin{array}{l}17 . \\
\text { stoletje }\end{array}$ & $\begin{array}{c}18 . \\
\text { stoletje }\end{array}$ & $\begin{array}{l}19 . \\
\text { stoletje }\end{array}$ & $\begin{array}{l}20 . \\
\text { stoletje }\end{array}$ \\
\hline $\begin{array}{l}\text { Kovinska industrija } \\
\text { (fužine za železo, predelava bakra) }\end{array}$ & - & $\bullet$ & - & - & - \\
\hline $\begin{array}{l}\text { Papirna industrija } \\
\text { (papir in igralne karte) }\end{array}$ & & $\bullet$ & $\bullet$ & - & \\
\hline $\begin{array}{l}\text { Tekstilna industrija } \\
\text { (suknarna, predilnica, barvarna) }\end{array}$ & & • & & - & - \\
\hline $\begin{array}{l}\text { Prehrambna industrija } \\
\text { (tovarna testenin, pivovarna, žganjar- } \\
\text { na, obrat za luščenje riža, mehanični } \\
\text { in valjčni mlin) }\end{array}$ & & & & - & - \\
\hline Proizvodnja elektrike & & & & - & - \\
\hline $\begin{array}{l}\text { Kemična industrija } \\
\text { (kresilne gobe) }\end{array}$ & & & & - & \\
\hline
\end{tabular}

\section{Viri: glej besedilo.}

*Tabela vključuje samo panoge, ki so se pojavile do vključno i9. stoletja.

O zgodnjem in razmeroma močnem razvoju moderne industrije priča tudi zapis v franciscejskem katastru, ki je toliko povednejši, ker zaradi svoje naravnanosti h kmetijstvu ta vir načeloma ne poudarja neagrarnih dejavnosti. A v operatu za Ajdovščino iz leta 1830 beremo:

Tovarna papirja in nova bombažna predilnica nedvomno pripomoreta $k$ vsakodnevni zaposlitvi lepega števila oseb. Računamo, da se enako število, če ne še večje, posveča industriji in različnim obrtem, predvsem strojenju kož, tako da je mogoče opredeliti, da se tretjina prebivalstva [katastrske] občine preživlja od industrije, preostali dve tretjini pa od kmetijstva. (AST, CF, SE, 10/1, Oec S/5) 


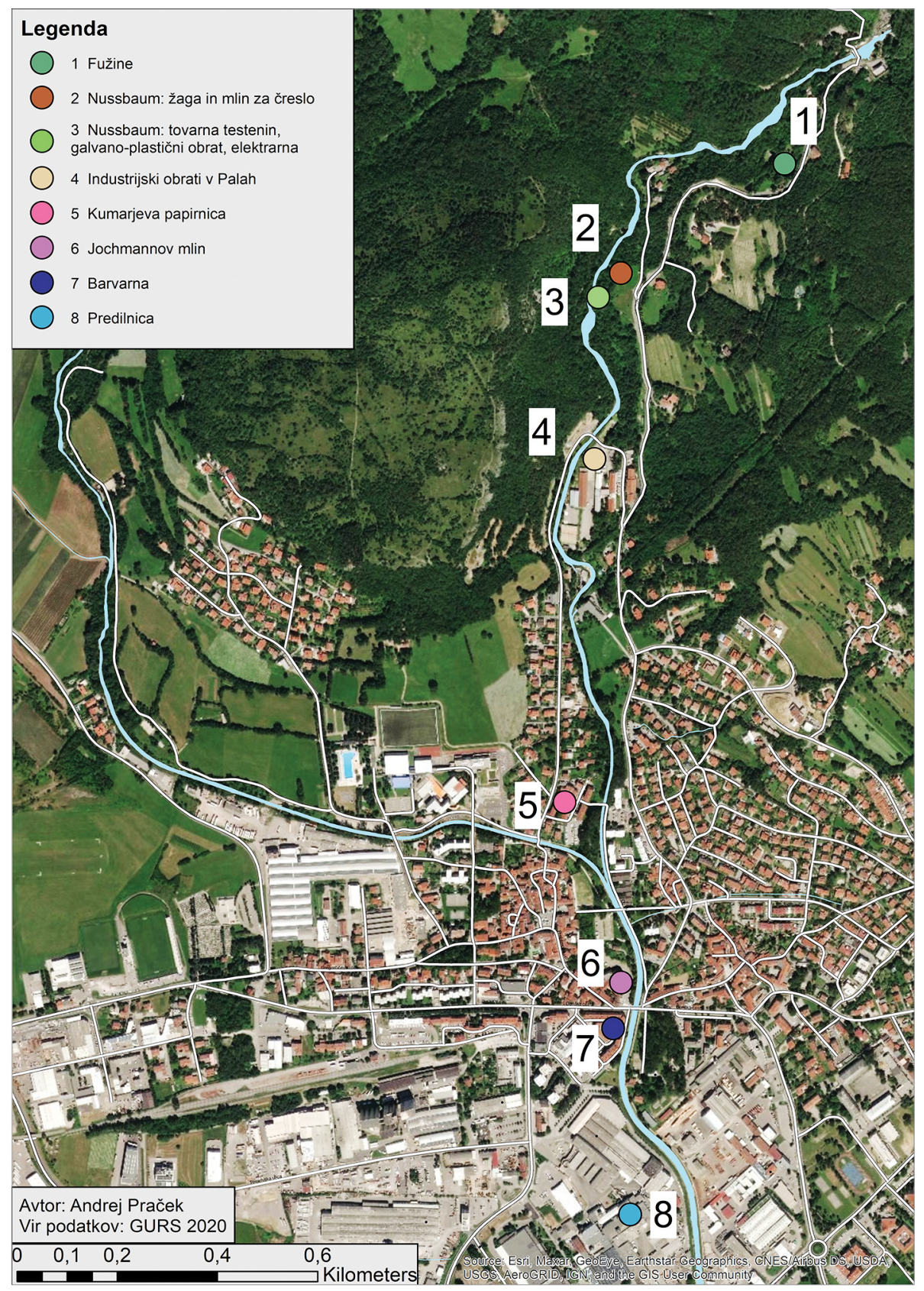

Karta i. Zemljevid osredotočenih industrijskih obratov v Ajdovščini od i6. do i9. stoletja 
To pomeni, da je že leta 1830 kar tretjina prebivalstva Ajdovščine živela od dela v panogah sekundarnega sektorja, polovica od katerih, to je šestina (16\%), je bila zaposlena v dveh večjih osredotočenih obratih. Tedaj (leta 1827) je kraj štel 662 prebivalcev, ki so živeli v 154 družinah.

Razloge za takšen razvoj gre iskati v naravnih virih in geostrateški legi kraja. Eden od odločilnih faktorjev lokacije je bila gotovo reka Hubelj, ki je obratom nudila vodo in pogonsko silo. Druga pomembna naravna vira sta bila gozd in ruda v bližini vode, ki sta dopolnjevala idealne pogoje za začetke fužinarstva. Poleg tega so gozd izkoriščali tudi za nabiranje gob, surovine za »tovarno « kresilnih gob, ki je nastala na mestu papirnice. Gotovo je $\mathrm{k}$ prednostim smotrno prištevati tudi to, da se Ajdovščina nahaja ob prometnici, ki je skozi Vipavsko dolino povezovala ne le Gorico in Ljubljano, temveč tudi širše slovenske in italijanske dežele. Cestne povezave in bližina mest Gorice in Trsta so bili pomembni faktorji tudi za vlagatelje v modernejše oblike industrije, posebej v primerih, ko jim okolica ni nudila potrebnih surovin in so jih morali zato uvažati, in obenem zaradi možnosti dostopa do izvoznih poti ter nenazadnje kot središči, ki sta ustvarjali naraščajoče povpraševanje. Prav verjetno ni naključje, da je industrijski razvoj Ajdovščine dobil nov zagon ravno v drugi polovici 18. stoletja, ko je novoustanovljeno tržaško prosto pristanišče začelo širiti svoje učinke na nekoliko širše zaledje. Nenazadnje lahko kot enega od razlogov navedemo tudi dolgotrajno kontinuiteto prisotnosti industrijskih dejavnosti, zaradi česar je ajdovsko lokalno prebivalstvo skozi generacije imelo izkušnje z delom v osredotočenih obratih in je bilo vajeno kombiniranja dela v kmetijstvu in industriji.

Če se pomaknemo bližje današnjemu času oziroma obdobju po drugi svetovni vojni, ko je mesto Ajdovščina doživelo drugi večji moderni razmah industrijskih dejavnosti, lahko kot enega od razlogov za to navedemo večstoletno tradicijo, na kateri sta temeljili in še danes temeljita pretežno prehrambna in tekstilna industrija. Poleg teh so se razvile tudi druge oblike industrije. Nova in inovativna podjetja, ki danes delujejo v Ajdovščini, to tradicijo uspešno nadaljujejo, mesto in njegovi prebivalci pa jo kot dediščino kraja skrbno negujejo.

Prispevek je nastal v sklopu razstavnega projekta »Industrijska dediščina Ajdovščine«, ki ga pripravlja Goriški muzej v sodelovanju z Lavričevo knjižnico, financiranega s strani Ministrstva za kulturo in Občine Ajdovščina, 


\section{ter dela, sofinanciranega iz raziskovalnega projekta ARRS J6-1799 »Koncepti kmečke ekonomije«.}

\section{Viri in literatura}

Arhivski viri

AS: Arhiv Republike Slovenije, SI AS 1842

731: 731, Fužine na Hublju pri Ajdovščini, 1817-1842

ASGo, GC: Archivio di Stato di Gorizia, Genio civile

676, 2303: šk. 676, mapa 2303, Aidussina, Consorzio dell'Hubel, 1926-1934. 676, 2301: šk. 676, mapa 2301, Aidussina, Rieter Emma ved. Guyer. Riconoscimento di derivazione d'acqua dal Torrente Hubel, 1927-1937

Aidussina, Società Anonima Elettrificio dell'Hubel, 1920-1936, šk. 705, mapa 2701.

ASGO, TT: Archivio di Stato di Gorizia, Tavolare Teresiano

110, 143, 685: Libri degli strumenti tavolari (1761-1891), šk. 110, tom. 143, str. 685

ASPG: Archivio Storico Provinciale di Gorizia

ASP II, 578: Atti degli Stati Provinciali, sezione II, šk. 578

AST, CF: Archivio di Stato di Trieste, Catasto franceschino

M 5b I: Mappe colorate di primo rilevamento (1821), Ajdovščina, šk. 5 b, karta I.

M, 254b IX: Mappe colorate di primo rilevamento (1821), Lokavec, šk. 254b, karta IX.

M, 254C 9: Mappe non colorate di secondo rilevamento (1873), Lokavec, šk. 254C, karta 9.

SE, 9/4, BP: Serie Elaborati, Ajdovščina, šk. 9/4, Protocollo particelle edifici / Bau Parcellen von Heidenschaft (1822).

SE, 10/1, Oec S/5: Serie Elaborati, Ajdovščina, šk. 10/1, Operato d'estimo catastale (S/5.17.20.21) / Catastral-Schatzungs-Operat der Steuer Gemeinde Haidenschaft (1830).

SE, 399/4 PBP: Serie Elaborati, Lokavec, šk. 399/4, Protocollo particelle edifici / Protocoll der Bau Parcellen der Gemeinde Locavitz (1822).

PANG TG: Pokrajinski arhiv Nova Gorica, Tribunal Gorica, zadružni register 296, C. 1-23: šk. 296, reg. C. 1-23, Elektrarna na Hublju, Ajdovščina $1922-1933$. 
525, 250, I-41: Fond 525, šk. 250, sign. I-41, Reiter Emma Guyer, mlin Pale; IX 1863/117, 1884-1889.

ŠAK, ŽV: Škofijski arhiv Koper, Župnija Vipava

SA II: Status animarum, zvezek II (1830)

\section{Objavljeni viri}

\section{ALZ: Amstsblatt zur Laibacher Zeitung}

15. 12. 1856 , št. 288

25. 2. 1858 , št. 45

AN: Ajdovske novice. Glasilo Občine Ajdovščina

15. 9. 2011, št. 4.

CCIG 1858: Rapporto generale della camera di commercio ed industria del Circolo di Gorizia rassegnato all'eccelso I.R. Ministero del commercio sopra le nazioni statisttiche dessunte a tutto 1858. Gorizia: Paternolli 1859/60.

CCIG 1888: Relazione sommaria presentata all'eccelso I.R. Ministero del commercio dalla Camera di commercio e d'industria di Gorizia intorno le condizioni del suo distretto nell'anno 1888. Gorizia: Paternoli, 1889.

Edinost: Edinost.

8. 1. 1905 , let. 30 , št. 8 .

7. 1. 1927 , let. 52 , št. 8 .

Gorica: Gorica

HSHKÖ: Hof- und Staats-Handbuch des Kaiserthumes Österreich für das

Jahr 1856. Zwieter Theil. Wien: Aus der Kaiserlich-königlichen Hofund Staatsdruckerei. https://books.google.si/books?id=UXupıFEZvk${ }_{4} \mathrm{C} \&$ printsec $=$ frontcover $\& \mathrm{dq}=\mathrm{HOF}-+\mathrm{UND}+\mathrm{STAATS}-\mathrm{HANDBUCH}+$ DES+KAISERTHUMES+\%C3\%96STERREICH+F\%C3\%9CR+DAS\&hl $=$ sl\&sa $=X \&$ ved $=2$ ahUKEwjIvcrog (dostop dne 3. 8. 2020).

24. 4. 1909, let. 11, št. 30

LZ: Laibacher Zeitung

17. 7.1873 , št. 162

Novice: Novice kmetijskih, obertnijskih in narodskih reči

5. 11. 1853 , let. XI, št. 89.

OGC-WA 1873: Officieller General-Catalog, Weltausstellung 1873, Wien. https:// opacplus.bsb-muenchen.de/Vta2/bsb11157337/bsb:BVo13209303?queries $=13$ \&language $=$ de $\& c=$ default $($ dostop dne 3. 4. 2020). 
Slovenec: Slovenec. Političen list za slovenski narod

12. 5. 1894 , let. 22 , št. 108.

3.2.1906, let. 34, št. 27

SN: Slovenski narod

2. 7.1892 , let. 25 , št. 148.

17. 5 . 1905 , let. 38 , št. 113

Soča: Soča

16. 4 . 1897 , let. 27 , št. 16 .

16. 9. 1905 , let. 35 , št. 74 .

14. 4 . 1906 , let. 36 , št. 30 .

1. 8 . 1906 , let. 36 , št. 61 .

Tagespost: Tagespost

6. 7.1865 , št. 152 .

\section{Literatura}

Bačar, S. 2007. Hubelj, Ajdovščina, Šturje in sosednji kraji v zgodovinskih zapisih od konca 15. do začetka 17. stoletja. Nova Gorica; Ajdovščina: Goriški muzej, Občina Ajdovščina.

Bačar, S. 2013a. "Fužine ob Hublju.« V Vipavska dolina: neživi svet, rastlinstvo, živalstvo, zgodovina, umetnostna zgodovina, gmotna kultura, gospodarstvo, naravovarstvo, ur. J. Pavšič, 263-69. Ljubljana: Slovenska matica.

Bačar, S. 2013b. Voda, stopa, mlin: dokumentirani mlini na območju današnje občine Ajdovščina v zgodovinskih virih in zapisih. Kromberk: Goriški muzej.

Blaznik, P. 1938. »Kolonizacija Poljanske doline.« Glasnik muzejskega društva za Slovenijo 19 (1-2): 1-62.

Čibej, E. 2005. Izbrani spisi. Predmeja: Društvo za ohranjanje in varovanje naravne in kulturne dediščine Gora.

Golec, B. 2007. »Meščanska naselja Vipavske in njihove posebnosti do konca fevdalne dobe.«Kronika 55 (2): 201-30.

Granda, S. 1984. »Kmetijske razmere v Vipavski dolini v prvi polovici 19. stoletja." Goriški letnik 11: 55-65.

Iancis, P. 2001. Manifattori e lavoranzia: Le forme del lavoro a Gorizia nel Settecento. Mariano del Friuli: Edizioni della Laguna. 
Kobe-Arzenšek, K. 1979. »Tekstilna proizvodnja in njena industrializacija na Slovenskem od začetka 19. stoletja do leta 1918.« Doktorska disertacija. Univerza v Ljubljani.

Kozmik Vodušek, V., ur. 2017. Mlinotest 150 let: brez moke ne bo kruha. Avtor zgodovinskih tekstov J. Krečič. Ajdovščina: Mlinotest Živilska industrija. Krečič, D. 2018. Tekstina skozi čas: od ustanovitve do danes. Ajdovščina: Tekstina.

Luchitta, A. 2001. Scritti sulla storia economica di Gorizia e della sua Provincia: (secoli XVII-XX). Gorica; Trst: Istituto Giuliano di storia, cultura e documentazione.

Morelli, C. 1855. Istoria della Contea di Gorizia, vol. II. in III. Gorica: Premiata tipografia Paternolli.

Pavlin, V. 2017. Goriška - od zadnjih goriških grofov do habsburške dežele. Nova Gorica: Pokrajinski arhiv.

Plesničar, P. 1997. Ajdovščina, komentirana objava zgodovine Ajdovščine in Šturij. Nova Gorica: Pokrajinski arhiv.

Rajšp, V., in D. Trpin. 1997. Slovenija na vojaškem zemljevidu 1763-1787 (1804), zV. 3. Ljubljana: ZRC SAZU, Arhiv republike Slovenije.

Ratkajec, H. 2012. »Proces industrializacije in oblikovanje industrijske regije v prostoru severovzhodnega Jadrana (Furlanija, Primorska in Istra) (19001940).« Doktorska disertacija, Univerza na Primorskem.

Ratkajec, H. 2015. Industrializacija in prostor: Severni Jadran med AvstroOgrsko, Italijo in veliko gospodarsko krizo (190o-1940). Koper: Založba Univerze na Primorskem. http://www.hippocampus.si/ISBN/978-9616984-10-2.pdf

Slokar, I. 1962. "Začetki kemične industrije v Ljubljani in njeni okolici.» Kronika: časopis za slovensko krajevno zgodovino 10 (1): 30-35.

Šorn, J. 1954. »Starejši mlini za papir na Slovenskem."Zgodovinski časopis 8: 87-117.

Šorn, J. 1984. Začetki industrije na Slovenskem. Maribor: Založba obzorja.

Valvasor, J. V. 2009-2013: Čast in slava vojvodine Kranjske. 3. del. Faksimile prevod. Ljubljana: Zavod Dežela Kranjska.

Zupanc, M., in P. Falatov, ur. 1976. Razvoj elektrifikacije Slovenije: do leta 1945. Ljubljana: Tehniška založba Slovenije. 


\section{Summary}

The long history of industry in Ajdovščina.

The centralised manufacturing plants along the Hubelj river

- an outline from the $16^{\text {th }}$ to the early $20^{\text {th }}$ century

Located in the rural area of the Vipava valley, Ajdovščina is a settlement with a long industrial tradition. The article shows how industrial activities can be traced continuously from the early modern period to the present day. The central theme is the continuity of industrial activity in the countryside between the 16th and 19th centuries. To show that, the paper focuses, among the different forms of production in the secondary sector, which may be traced, on centralised manufacturing plants only. The resulting picture shows how centralised plants may be traced at least since to the mid16th century and how, with the emergence of new industrial productions, from the late $18^{\text {th }}$ century and through the 19 th an accelerated industrial development may be detected. Around 1830, one-third of the Ajdovščina population made their living on industrial work, the half of which did so in the two largest plants at that time (Ajdovščina in 1827 had 662 inhabitants, 154 families).

During the considered period, various industries such as the metal, paper, textile, chemical and food processing industries operated in Ajdovščina and its close surroundings, which are presented in the article on the examples of individual plants. An outstanding common denominator of these plants was their location along the river Hubelj, which provided one of the main conditions for their operation - the driving force, and thus constituted a central factor in location-choosing. Forest and ore resources were other important assets that further contributed to the strategic location of the town along the main traffic route connecting Slovene and Italian regions, but also the proximity of urban centres and the Adriatic Sea coast as well as the presence of a local workforce that was skilled due to the long industrial tradition. All of these may be identified as further factors that led to such a diverse range of activities by the Hubelj river over the centuries 